\title{
The Impact of Industrial Noise Exposure on Hearing Loss and Hypertension Decline of Labour in Central Java
}

\author{
$1^{\text {st }}$ Cr. Siti Utari \\ Medical Faculty of Sebelas Maret \\ University \\ Sebelas Maret University \\ Surakarta, Indonesia \\ sitiutari@staff.uns.ac.id
}

\author{
$2^{\text {nd }}$ Endang Sutisna \\ Medical Faculty of Sebelas Maret \\ University \\ Sebelas Maret University \\ Surakarta, Indonesia \\ sutisnaend_dr@yahoo.com
}

\author{
$5^{\text {th }}$ Hardiningsih \\ Medical Faculty of Sebelas Maret \\ University \\ Sebelas Maret University \\ Surakarta, Indonesia \\ stroop_berri@yahoo.com
}

\author{
$3^{\text {rd }}$ Seviana Rinawati \\ Medical Faculty of Sebelas Maret \\ University \\ Sebelas Maret University \\ Surakarta, Indonesia \\ shevie.ana@gmail.com \\ $6^{\text {th }}$ Agus Eka N Y \\ Medical Faculty of Sebelas Maret \\ University \\ Sebelas Maret University \\ Surakarta, Indonesia \\ ekayuneta@yahoo.com
}

\author{
$4^{\text {th }}$ Fresthy Astrika Y \\ Medical Faculty of Sebelas Maret \\ University \\ Sebelas Maret University \\ Surakarta, Indonesia \\ fresh_outside@yahoo.com
}

\begin{abstract}
Noise is the danger factor that influences all environment, both industrial environment and environment in general. The effect of noise can be a disturbance sense of hearing form of deafness. For examples is the lowering percentage of hearing level and for another impact is on hypertension. This study aimed on determining the effect of age and the tenure (work period) on hearing loss and hypertension of the laborer exposed to an industrial noise. This study used observational and analytical method with cross sectional approach. The populations were the laborer exposed to the textile industrial noise in Subosukawonosraten region of Central Java. The samples were taken through quota sampling technique from 210 people. The results have shown that the laborer exposed to the noise by intensity of 80-99 dB have been found that: 1) there is an effect of age and tenure (work period) on the percentage of hearing loss, 2) there is an influence of age and tenure (work period) towards the hypertension of the laborer. It is concluded that the noise in the intensity of 80-99 $\mathrm{dB}$ affects the hearing loss and hypertension of laborer.
\end{abstract}

Keywords—noise, hearing loss, hypertension, textile industrial

\section{INTRODUCTION}

In 2005, WHO released"Sound Hearing Program 2030", which hasa mission to reduce hearing loss disturbance in 2030 through the development of a sustainable health system. The target is to reduce hearing loss disturbance by $50 \%$ in 2015 and $90 \%$ in 2030 [1]. Furthermore, [1] states that the purpose of the development is to produce Indonesian people who are intelligent, critical, and productive; the sense of hearing is an essential part in creating a productive person. When a person has a lowering percentage in hearing level, the quality of life will decline too. Thus, the problem of hearing level is essential for both personal life, community and within countries.

A disorder as mentioned above is anauditory disorder, while non auditory disorders include disorders of communication, psychology and balance [2]. A high noise will cause cardiovascular disorders, allergies, and sore throat [3]. The finding of this study shows that a high noise can increase blood pressure. There is a difference between blood pressure in a high noise and low noise. This occurs because of stress from the effects of noise. A labour who has worked in the environment that has high noise levels sometimes will have an impact on the psychology, one of which is stress. Based on the data processing, namely noise intensity obtained $108.62 \mathrm{dBA}$ on diesel unit on the 1st floor and $106.99 \mathrm{dBA}$ on the 2nd floor, while the Boiler unit 1 intensity noise was $92.53 \mathrm{dBA}$ and 93.99 $\mathrm{dBA}$ at Boiler unit 2. the perceived impact of noise experienced by workers as a result of that communication disorders, hearing/auditory and psychological disorders [4]. Besides, noise can also cause anxiety. Anxiety will have an influence on physiology (heartbeat) and will eventually raise blood pressure of someone. there was significant affect of noise to sistole blood pressure (sig. $\alpha=0,039<0,05$ ) and diastole blood pressure (sig. $\alpha=0,019<0,05$ ) [5]. Communities in the region of Central Java exposed to noise at various places are the labour in the textile industry, communities around the textile industry, as well as.

The people who live around the flow of traffic such as airports and highways. The research on the impact of noise around the highway in Yogyakarta [6], shows that there is a relation between noise intensity and the increase of diastolic blood pressure $(p=0.019)$, whereas at the level of deafness occurs a significant increasing $(\mathrm{p}=0.026)$. The relationship between the noise with hearing impairment workers can be 
seen from several factors, including: the intensity of the noise, the results of audiometric tests, age, and tenure [7], demonstrates that there is a relationship between the noise intensity and the increase of diastole blood pressure $(\mathrm{p}=0.001)$. This study will examine further about the magnitude of the noise impact of the labour, as well as the policy control that must be done by the government a cross the sectors.

\section{MAterials AND METHODS}

This study used analytical survey with cross sectional method, conducted in Subosukawonosraten (Surakarta, Boyolali, Sukoharjo, Karanganyar, Wonogiri, Sragen and Klaten), Central Java, Indonesia. The populations in this study werethe labour exposed to noisy industry in the region of Central Java Subosukawonosraten (7 clusters). The sample was taken by quota sampling technique. For each cluster, it took 30 people. The total number of samples $=30 \times 7=210$ people. However, this study found some invalid data as many as 190 people.The research instrument: a) Sound level meter, to measure the intensity of noiseb) Audiometer, to measure the value of the hearing level in the sense of hearing c) Tensimeter, to measure blood pressure d) Data of staffing firm, to determine the service life of the labour e) Identity Card (ID), to determine the age of the labour f) Questionnaire, to determine the research supporting data.

\section{RESULT AND DISCUSSION}

The characteristics ofresearch sample are described based on age and the tenure (working period) and it is shown in Figure1. The figure shows the research sample characteristics ofthe labourer (190 women).

Result of the study showed the age of labor in category $<40$ years old is $61 \%$ and $>40$ years old is $39 \%$. While for tge working time as showed as pic 1:

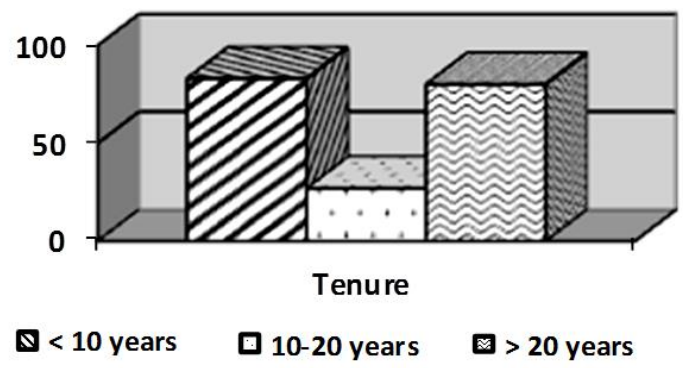

Fig. 1. The Characteristics of Research Sample (Tenure)

Based on the picture 1 showed that most of labor working less than 10 years $(83 \%)$

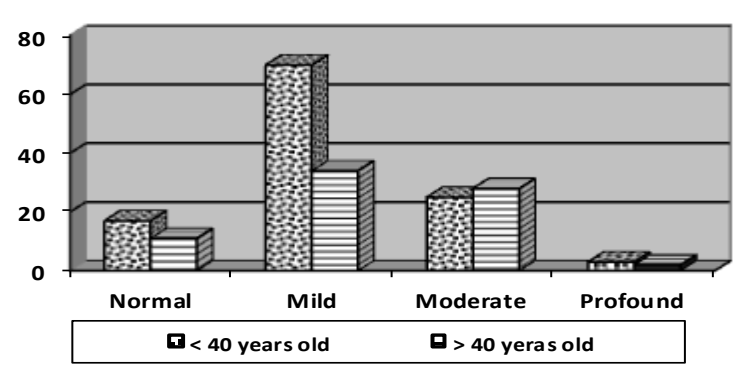

Fig. 2. The Measurements Result of Right Ear Hearing loss by Age of Labourer

The statistical test result using Chi Square Testin figure 2, shows the value of $\mathrm{X} 2=5.96$ at $\mathrm{p}=0.114$. Thus, it can be stated the test result is not significant. It can be stated that there is no significant relation between age and the level of deafness of the righ tear.

\section{A. The Relationship Between Age and Hearing Loss of The Left Ear}

The figure 3 shows that the statistical test by using Chi Square Test, the value of $\mathrm{X} 2=8.81$ at $\mathrm{p}=0.032$. Thus, it can be stated that the test result is significant, and so it can be stated that there is a significant relation between age and the level of deafness of the left ear.

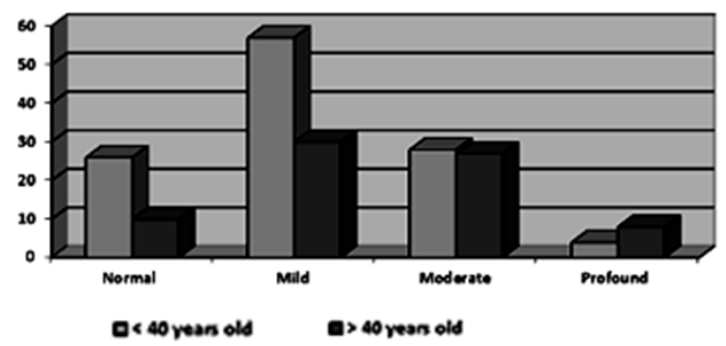

Fig. 3. The Measurements Result of Left Ear Hearingloss by Age of the Labourer.

B. Relationship Between Tenure (Work Period) and The Right Ear Hearing Loss of The Labourer.

In the figure 4, the statistical test using Chi Square test shows the value of $\mathrm{X} 2=28,63$ at $\mathrm{p}=0.000$. Thus, it can be stated test result is significant, and so it can be stated that there is a significant relation between tenure work periodand the level of deafness in the right ear. 


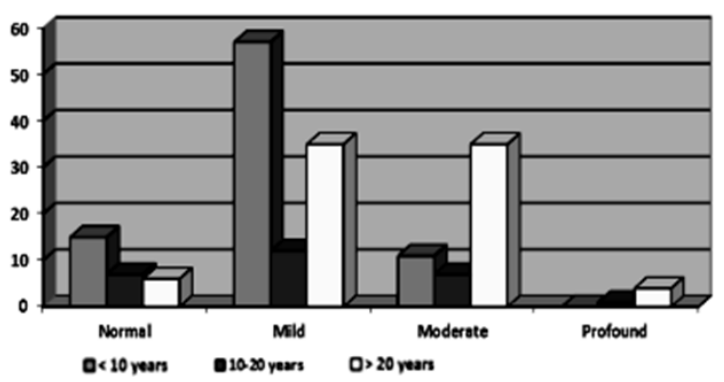

Fig. 4. The Measurements Result of the right ear hearing loss by tenure of the labourer.

\section{The Relationship Between Tenure and Left Ear Hearing Loss of The Labourer.}

In The Figure 5, the statistical test using Chi Square test shows the value of $\mathrm{X} 2=38.40, \mathrm{p}=0.000$. Thus, it that test result is significant, and so it can be stated that there is a significant relation between tenure and the level of deafness in the left ear.

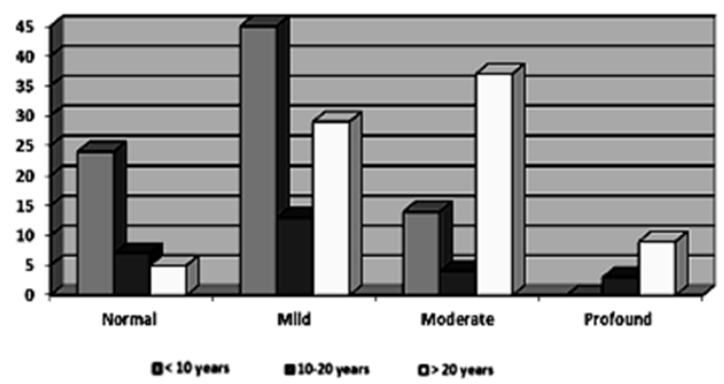

Fig. 5. The Measurement Result of left ear hearing loss by tenure of the labourer

\section{The relationship between age and blood pressure of the laboureris.}

The Measurement Result of blood pressure by age of the labourer that The labor in the age <40 years old is more $(53,9 \%)$ than the age above 40 years old. Meanwhile the labor who has a hypotension in the age $<40$ years old is more $(33 \%)$ than the age $>40$ years old and the labor who has a hypotension in the age $<40$ years old is more $(13 \%)$ than the age $>40$ years old.

The statistical test result using Chi Square test shows the value of X2 $=30.34$ at $p=0,000$. Thus, it that the test result is significant, and so it can be stated that there is a significant relation between age and hypertensions.
E. The Relationship between tenure and blood pressure of the labourer is presented in the figure 8.

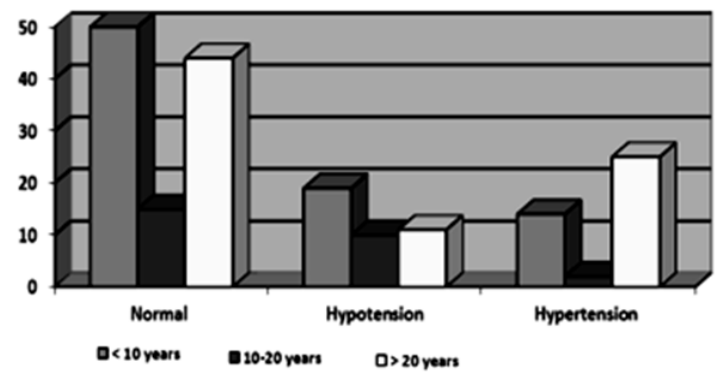

Fig. 6. The Measurement Result of blood pressure by tenure of the labourer.

The figure 6 shows that the statistical test by using Chi Square test values obtains $\mathrm{X} 2=12,48$ at $\mathrm{p}=0.014$. Thus, it can be stated that thetest result is significant, and so it can be stated that there is a relationship between age and hypertension.

a. The relationship between age and the lowering percentage in hearing level of all labourer who are exposed to noise in a company (190 people). In table 8 , it can be seen the description of age and the lowering percentage in hearing level of all labourer exposed to noise in a company (190 people).

TABLE 1. THE LOWERING PERCENTAGE IN HEARING LEVEL OF ALL LABOURER EXPOSED TO NOISE IN A COMPANY (190 PEOPLE)

\begin{tabular}{|c|c|c|c|c|c|c|c|}
\hline No. & Variable & Atrerage & $\begin{array}{l}\text { Deviation } \\
\text { Stundurd }\end{array}$ & Min & Max & $\mathbf{R}$ & $\mathbf{p}$ \\
\hline 1. & Age (year) & 35.99 & 936 & 17 & 60 & & \\
\hline 2. & $\begin{array}{l}\text { \% Loweting percentage in } \\
\text { hearing lewel of Right Ear }\end{array}$ & 18.07 & 12.75 & 0.00 & 64.10 & 0.353 & 0.000 \\
\hline 3. & $\begin{array}{l}\text { \% Lowering perverdtage in } \\
\text { hearing level of Left Ear }\end{array}$ & 2231 & 14.99 & 0.00 & 7L. 10 & 0337 & 0.000 \\
\hline 4. & $\begin{array}{l}\text { \% Lopering perentage in } \\
\text { beating lewel of doulble tars }\end{array}$ & 16.83 & 12.31 & 0.00 & 62.56 & 0.311 & 0.000 \\
\hline
\end{tabular}

b. The relationship between age and the lowering percentage in hearing level of the labourer at the age of $\leq 40$ years old. The description of the lowering percentage in hearing level of the labourer exposed to noise in a company at the ageof $\leq 40$ years old is listed in table 2 .

TABLE 2. THE LOWERING PERCENTAGE IN HEARING LEVEL OF THE LABOURER EXPOSED TO NOISE IN A COMPANY AT THE AGE OF $\leqslant 40$ YEARS OLD

\begin{tabular}{|c|c|c|c|c|c|c|c|}
\hline $\mathbf{N o}$ & Variable & Average & $\begin{array}{l}\text { Deviation } \\
\text { Standand }\end{array}$ & Min & Max & $\mathbf{R}$ & p \\
\hline 1. & Age (year) & 30.22 & 7.36 & 17 & 40 & & \\
\hline 2. & $\begin{array}{l}\% \text { Lowering percentrge in } \\
\text { herring level of Right Exr }\end{array}$ & 16.12 & 13.02 & 0.00 & 63.60 & 0.254 & 0.006 \\
\hline 3. & $\begin{array}{l}\text { \% Lowering percentage in } \\
\text { herring level of Let Ear }\end{array}$ & 17.99 & 13.36 & 0,00 & 69.40 & 0.220 & 0.018 \\
\hline 4. & $\begin{array}{l}\text { \% Lowering percentage in } \\
\text { herring level of double } \\
\text { ers }\end{array}$ & 14.86 & 11.46 & 0,00 & 56.88 & 0.246 & 0.008 \\
\hline
\end{tabular}


The description of the lowering percentage of hearing level of the labour exposed to noise in the company at the age of $\geq$ 40 years old is presented in Table. 3.

TABLE 3. THE LOWERING PERCENTAGE OF HEARING LEVEL OF THE LABOURER EXPOSED TO NOISE IN A COMPANY AT THE $A G E$ OF $\geqslant 40$ YEARS OLD

\begin{tabular}{|c|c|c|c|c|c|c|c|}
\hline No. & Variable & AFarige & $\begin{array}{l}\text { Devistion } \\
\text { Strmidend }\end{array}$ & Min & Max & $\overline{\mathbf{R}}$ & $\mathbf{p}$ \\
\hline 1. & Age (Yar) & 44.75 & 3.50 & 41 & 60 & & \\
\hline 2. & $\begin{array}{l}\text { \% Lowring perrentage } \\
\text { in hearing level of Right } \\
\text { Er }\end{array}$ & 19.12 & 1285 & 0.00 & 64.10 & -0.193 & 0.097 \\
\hline 3. & $\begin{array}{l}\text { \% Lowaring percenthge } \\
\text { in hearing level of Left } \\
\text { Err }\end{array}$ & 22.73 & 15.19 & 0.00 & 71.60 & -0.154 & 0.188 \\
\hline 4. & $\begin{array}{l}\text { \%owering perceutage } \\
\text { in bearing level of } \\
\text { double exs }\end{array}$ & 17.52 & 12,42 & 0.05 & 57.56 & -0.223 & 0.054 \\
\hline
\end{tabular}

The measurement result of noise intensity in spinning mill area company is 80-99 dBA [8]. The source of noise from spinning machine. The relationship between age and hearing loss of the labourer. The complete measurement result of hearing loss is presented in Table 2. The age description of the labourer from 190 people is divided into two groups, namely a group of people at the age of less than or equal to 40 years old amounted to 115 people, and a group of people at the age of over 40 years old amounted to 75 people. Then, the measurement of hearing loss using the audiometer to 190 samples is done at a frequency of $500 \mathrm{~Hz}, 1000 \mathrm{~Hz}, 2000 \mathrm{~Hz}$, and $4000 \mathrm{~Hz}$. The measurement result of hearing loss is the average of the lowest sound intensity that can still be heard by subject on the fourth frequency. Then, the measurement results are classified into [9]:

1) Normal, if the average of hearing loss is less than $25 \mathrm{~dB}$.

2) Mild hearing loss, if the average of hearing loss is between 25-40 dB.

3) Moderate hearing loss, if the average of hearing loss is between 40-55 dB.

4) Profound deafness, if the average of hearing loss is between 55 to $70 \mathrm{~dB}$.

A labor who has severe deafness gas a working time $>20$ years, meanwhile there is no severe deafness labor in the $<10$ years working time. This is appropriate with the study to 5 deaf labors between 35-45 years old. According to Premenaker no 25 2008, a labor in the age $>40$ years old the hearing ability ia decrease 0,5 dB. According to Ologe (2008) said that the age average of the lack of hearing is range in 20-50 years old [7].

The description of the lowering percentage in hearing level based on age of the labourer exposed to noise in a company will be explained below. To find out how big is the lowering percentage in hearing level by age, it has been done a test from the relationship between age and lowering percentage in hearing level. The lowering percentage in hearing level is calculated in percentage (\%). The test of the relationship between age and lowering percentage in hearing level of all labourer who are exposed to noise in a company amounted to 190 people is intended to determine whether the age is also followed by the lowering percentage in hearing level or not. The second test is about the relationship of lowering percentage in hearing level of labourer at the age of underor equal to 40 years old. It is done to know whether the younger age has shown the lowering percentage in hearing level or not. Meanwhile, the third test is about the relationship between age and the lowering percentage in hearing level of the labourer at the age of over 40 years old. The test is intended to determine whether or not the age under and over 40 years old will have a difference in the severity of hearing level calculated in a percentage $(\%)$.

The relationship of age and the lowering percentage of right ear hearing level of all labourerin table 1, it can be seen that the test result between age and lowering percentage in right ear hearing level of all labourer shows the correlation value of $(r)=$ 0.353 and $p=0.000$. Because the value of $p<0.05$, the test result is significant. It can be concluded that there is a significant relationship. Because the value of $r$ is positive, then it is stated that the more increasing age, the more increasing of lowering percentage in hearing level will be.

The relationship between age and the lowering percentage in left ear hearing level of all labourer base on the table 1 shows the test result of the relationship between age and the lowering percentage in the left hearing level of all labourer. It shows the correlation value of $(r)=0.337$ and $p=0.000$. Because the value of $\mathrm{p}<0,05$, the test result is significant. Thus, it can be concluded that there is a significant relationship. Because the value of $r$ is positive, then it is stated that the more increasing of age, the more increasing of lowering percentage in hearing level will be.

The relationship between age and the lowering percentage in double ears hearing loss of all laboureron the table 1 presents the result of the test from the relationship between age and the lowering percentage in double ears hearing level of all labour. It shows the correlation value of $(r)=0.311$ and $p=$ 0.000 . Because the value of $p<0.005$, the test result is significant. It can be concluded that there is a significant relation. Because the value of $r$ is positive, then it is stated that the more increasing of age, the more increasing of lowering percentage in hearing level will be.

To determine the relationship between age and lowering percentage in hearing level of right ear, left ear, and double ears of the labour at the age of $\leq 40$ years old, it has been done a statistical test by using Pearson Product Moment Test.

In table 2, it is presented the results of the test from the relationship between age and lowering percentage in the right ear hearing level of labour at the age of $\leq 40$ years old. It shows the correlation value of $(r)=0,254$ and $p=0.006$. Because the value of $\mathrm{p}<0.05$, the test result is significant. So, it can be concluded that there is a significant relationship. Because the value of $r$ is positive, it is stated that the more increasing age, the more increasing of lowering percentage in hearing level will be.The relationship of age and the lowering percentage of left ear hearing level of the labourer at the age of $\leq 40$ years old. In table 2 , it is presented the result of the test from the relationship between age and the lowering percentage of left ear hearing level of the labourer at the age of less than or equal to 40 years old. The table shows the correlation value of $(r)=0.220$ and $p=0.018$. Because $p<0.05$, the test result is significant. Because the value of $r$ is positive, it is stated that 
the more increasing age, the more increasing of lowering percentage in hearing level will be.

Based on the table 2, it can be seen the test result from the relationship between age and the lowering percentage of double ears hearing level of the labourer at the age of $\leq 40$ years old. The table shows the correlation value of $(r)=0,246$ and $p=0,008$. Because the value of $p<0$. 05, the test result is significant. It can be concluded that there is a significant relationship. Because the value of $r$ is positive, it is stated that the more increasing age, the more increasing of lowering percentage in hearing level will be, same wiht Dino that based on age, obtained information that the respondents aged 21-35 years is the largest user of PPE which is about $67.8 \%$ and above 46 years of age to use PPE approximately 37.2\% [10].

Based on the table 3, it can be seen the test result from the relationship between age and the lowering percentage of right ear hearing level of the labourer at the age of $\geq 40$ years old. It shows the correlation value $(r)=-0.193$ and $\mathrm{p}=0.097$. Because the value of $p>0.05$, the test result is not significant. It is concluded that there is no significant relation. Thus, at the age of more than 40 years old, the increasing of age is not followed by the lowering percentage in hearing level [11].

The test result from the relation between age and the lowering percentage of left ear hearing level of the labour at the age of $\geq 40$ years old (tabel 3 ), it shows the correlation value of $(r)=-0.154$ and $p=0,188$. Because the value of $p>$ 0.05 , the result is not significant. It can be concluded that there is no significant relationship. Thus, at the age of more than 40 years old, the increasing of age is not followed by the lowering percentage in hearing level.

Table 3, it can be seen the test result from the relationship between age and lowering percentage of double ears hearing level of the labourer at the age of $\geq 40$ years old. The table shows a correlation value of $(r)=-0.223$ and $p=0.054$. Because the value of $p>0$. 05, so the test result is not significant. It can be concluded that there is no significant relationsip. Thus, at the age of more than 40 years old, the increasing of age is not followed by the lowering percentage in hearing level.

\section{CONCLUSION}

It is concluded that the noise in the intensity of $80-99 \mathrm{~dB}$ affects the lowering percentage in hearing level and hypertension of the labour in Central Java, based on the current study seems to suggest that workers should not be exposed to more than $89 \mathrm{~dB}$ as this had the least systolic and diastolic blood pressures [19].

\section{ACKNOWLEDGMENT}

The authors thank Associate Professor Dr. Bhisma Murti., MPH., M.Sc., PhD for providing in valuable assistance in obtaining and analyzing data.

\section{REFERENCES}

[1] Bashiruddin Jenny, 2010, Prevent Hearing Loss, Improve Quality of Life, Universitaria-February Edition 2010
[2] Buchari, 2007, Industries Noisedan Hearing Conservation Program, USU Repository @ 2007.

[3] Bell, Fisher, Baum, dan Greene. 1996. Environmental psychology. Fourth Edition Florida: HarcoutBracoColega Publisher.

[4] Prima Fithri, Indah Qisty Annisa, 2015, Industry of noise intensity in work Area Utilities Unit PLTD and Boiler at PT.Pertamina RU II Dumai. Jurnal Sains, Teknologi dan Industri, Vol. 12, No. 2, Juni 2015, pp. 278 - 285 ISSN 1693-2390 print/ISSN 2407-0939 online. Andalas University.

[5] Wenny Wuladani, Salamiah, Akhmad Rizali, Eko Suhartono, 2015, analysis affect of noise to hearing function and blood pressure at tyre worker in workshop PT. Rahman Abdijaya in Tabalong. EnviroScienteae 11 (2015) 122-130 ISSN 1978-8096. Tabalong

[6] Suryani Dyah (2008), Noise, Long Live, Blood Pressure and Threshold of Hearing Community atUmbulharjo Yogyakarta Terminal; Kesmas,Vol.2,No.3, September 2008:133:193.

[7] Noor Amalia Chusna, Haryono Setiyo Huboyo, Pertiwi Andarani, 2017, Analysis Noice Factory Equipment to Hearing Loss Workers in PT. Pura Barutama Unit Paper Mill 5.6.9 Kudus. http://ejournals1.undip.ac.id/index.php/tlingkungan Enviroment of Technic Journal, Vol. 6, No. 1 (2017). Diponegoro University. Semarang.

[8] The Ministry of Manpower and transmigration Indonesian, 2011, Regulation The Ministry of Manpower and transmigration Indonesian Number Per.13/Men/X/2011 About Threshold Limit Values Factors Physical and Chemical Factors in the Workplace.

[9] The Ministry of Manpower and transmigration Indonesian, number: Per 25/Download/VII/2008 about the guidelines of Diagnosis and assessment of Disabilities due to accidents and Occupational Diseases.

[10] Dino Rimantho, Bambang Cahyadi. 2015. analyzes occupational noise exposure and the use of personal protective equipment noise in several different industries in Jakarta. Technology Journal. Volume 7 No. 1 Januari 2015 ISSN : 2085 - 1669. e-ISSN : 2460 - 0288 Website : jurnal.ftumj.ac.id/index.php/jurtek

[11] Heryudarini H, Hardinsyah, Budi S. Dan Imam E. 2008. The relation Body Mass Index, Gender, Age, Blood and History Descendants with Blood Pressure on Civil Servants at Pekanbaru. PGM. 2008, 31(2): 5158.

[12] Bluhm, Berglind, Nordling and Rosenlund. 2007. Road traffic noise and hypertention. Journal of Occupational and Environmental Medicine. Volume 64, Issue 2, February 2007, Pages 122-126.

[13] De Kluizenaar, Gansevoort, Miedema and De Jong. 2007. Hypertention and road traffic noise exposure. Journal of Occupation and Environmental Medicine. Volume 49, Issue 5, May 2007, Pages 484492.

[14] Salami O. Ismaila and Adebayo Odusote. 2014. Noise exposure as a factorin the increase of blood pressure of workers in a sack manufacturing industry. Beni-Suef University journal of basic and applied sciences 3 (2014) 116-121.

[15] SetiawatiEvi. 2011. Study Predicts Increased Noise Due to construction in the Neighbourhood Region Along the Railway Cirebon cross Kroya. J. Pengemb. Rek\&tek. Volume 13 no 2.

[16] Suroto Widi, 2010, Traffic Noise Impact Settlement Against City (Surakarta Case),Journal of Rural and Development.Volume 1 No. 1 Februari 2010.

[17] Viraporn A. Evaluation of Noise Induced Hearing Loss With Audiometer and Disortion Product Otoacoustic Emissions. J. Med Assoc Thai, 2008. vol. 91, no. 7. 1066-71.

[18] Elena Ascar, Gaetano Licitra, Luca Teti, Mauro Cerchiai. 2015. Lowfrequency noise impact fromroad traffic according to different noise prediction methods. Science of the Total Environment 505 (2015) 658669. journal homepage: www.elsevier.com/locate/scitotenv. Elsevier.

[19] Salami Olasunkanmi Ismaila*, Adebayo Odusote. 2014. Noise exposure as a factor in the increase of blood pressure of workers in a sack manufacturing industry. beni-suef university journal of basic and applied sciences 3(2014) 116e121. journal homepage: www.elsevier.com/locate/bjbas.

[20] SubarisHeru dan Haryono. 2008. Hygiene of Work Environment. Mitra Cendikia Press. Jogjakarta. 
[21] Suma'mur PK, 2009, Occupational Health and Safety, Sagung Seto, Jakarta.

[22] http://sindoradio.com/news/detail/1841/noise-can-cause-deafness. $06 \mathrm{Jul}$ 2012 15:32WIB.

[23] Montolalu SS, Wenny Supit dan Vennetia R. Danes. 2013. The Relations of Noise to Blood Pressure On Mobile Workers at PT. Gapura Angkasa, Sam Ratulangi Airport, Manado.

[24] Saryawati Ratna. 2008. Genesis Hypertension Risk Factors in Textile Industry Workers. University of Diponegoro Semarang.

[25] The Ministry of Manpower and transmigration Indonesian. 2009. What You Know About Hearing Conservation (Practical Handbook).Occupational Health and Safety Center. Jakarta.

[26] The Minister of the Environment, 1996, Decree of the Minister of the Environment No. 48, 1996About Raw Noise Level. 